\title{
Spatial diversity of forest regeneration after catastrophic wind in northeastern Poland
}

\author{
Janusz Szmyt ${ }^{(1)}$, \\ Dorota Dobrowolska ${ }^{(2)}$
}

\section{Introduction}

The recognition that ecosystems are dynamic and that disturbances play a key role in the development of many ecosystems was an important paradigm proclaimed among ecologists and resource managers during the $20^{\text {th }}$ century (Panayotov et al. 2011). Natural disturbances (e.g., storm events) are now recognized to be among the most important processes that guide forest dynamics (Oliver \& Larson 1996, Panayotov et al. 2011, Budzáková et al. 2013) because of their effects on forest strucresource availability. In most cases, windture, species composition, patchiness and

\begin{abstract}
We examined the spatial diversity of young growth established after the catastrophic windthrow occurred in 2002 in the northeastern part of Poland. Our observations and measurements were conducted on permanent circular measurement plots located in the Szast Protected Forest (continental lowland temperate forests) that were established 3 years after the windstorm and left to natural succession. We evaluated the spatial indices characterizing the four main aspects of stand structure: the spatial arrangement of seedlings and saplings, species mingling, tree size diversity at the local spatial scale and the overall structural complexity index. The calculations were conducted in parts of the forest with differing severity of disturbance. The obtained results indicated the prevalence of a random arrangement of young growth. Clumps of regeneration were observed to a lesser degree in all parts of the forest. The species diversity was moderate and was the highest in the slightly or severely disturbed stands. Scots pine formed homogenous groups of regeneration and oaks were intermingled among other tree species. The height of the natural regeneration was moderately or highly differentiated in all stands. The overall structural diversity index showed that stand regeneration in the slightly or moderately disturbed stands was more differentiated than the young growth in the severely disturbed stands. The size differentiation of young growth is a long-lasting process and thus should be considered in practices aimed at the re-growing of areas after a natural disturbance. This process might be used to the replace monocultures with more diversified forests even in poor forest site types.
\end{abstract}

Keywords: Spatial Diversity, Spatial Indices, Natural Regeneration, Windthrow, Forest Succession throws help to revive the habitat. The forest response following blowdown can occur by the recruitment of new individuals or release of the previously suppressed understory (Kulakowski \& Veblen 2003).

Severe wind storms are expected to increase in Europe, especially in the continental zone, and the role of such natural disturbances in shaping European forest ecosystems has received increasing attention (Ulanova 2000, Močalov \& Lässig 2002, Nagel et al. 2006, Shorohova et al. 2008, Svoboda \& Pouska 2008, Xi et al. 2008, Vodde et al. 2010, Dobrowolska 2010, Holzmueller et al. 2012, Budzáková et al.
(1) Department of Silviculture, Faculty of Forestry, Poznan University of Life Sciences, Wojska Polskiego 69, 60-625 Poznan (Poland); (2) Forest Research Institute, Department of Forest Ecology, Braci Lesnej 3, 05-090 Raszyn (Poland)

@ Janusz Szmyt (jszmyt@up.poznan.pl)

Received: May 06, 2015 - Accepted: Nov 05, 2015

Citation: Szmyt J, Dobrowolska D (2016). Spatial diversity of forest regeneration after catastrophic wind in northeastern Poland. iForest 9: 414-421. - doi: 10.3832/ifor1699-008 [online 2016-01-29]

Communicated by: Matteo Garbarino
2013, Mitchell 2013, Spathelf et al. 2014). Catastrophic windstorms usually cause the destruction of tree canopy and influence the environmental conditions (Ulanova 2000, Mitchell 2013). Different light availability and microsite heterogeneity influence forest regeneration in the years following a windthrow (Kuuluvainen \& Juntunen 1998, Wohlgemuth et al. 2002, Kuuluvainen \& Kalmari 2003, Holzmueller et al. 2012, Mitchell 2013). Kuuluvainen \& Juntunen (1998) noted the importance of microhabitat heterogeneity (pits and mounds, mineral soil exposition etc.) for regeneration in a mature Scots pine stand characterized by windthrow gaps. These researchers observed that birch seedlings occupied mostly the pits and mounds created by tree falls, while pine regeneration was mostly found on the uprooting spots. The early growth of recruits was determined by the type of microhabitats and the radiation environment as well as by the competition with neighboring individuals. Kuuluvainen \& Kalmari (2003) studied the regeneration microsites of Norway spruce seedlings in the old-growth forest disturbed by the wind in the boreal zone of Finland. Spruce seedlings were found the most often in disturbed microsites and immediately beside or on decayed wood. Vodde et al. (2010) stu- 
died the natural regeneration of heavily or moderately damaged windthrow areas in hemiboreal mixed forests in Estonia. Regeneration establishment and its growth were favored in the pits and mounds of uprooted trees. Moreover, they observed that seedling grow better in the large but shallow soil pits created by uprooted spruce, and poorer in the small but deeper pits created by hardwoods. The annual height growth of seedlings was higher in the heavily damaged areas than in the moderately damaged ones, and the best height was observed for rowan seedlings followed by birch, alder and spruce (Vodde et al. 2010). Mitchell (2013) noted that forest recovery after extreme weather events depended on the severity and extent of the damage, the release of the understory trees or colonization of available growing space by new regeneration, influencing the tree species succession. For example, if the windthrow removes light-demanding tree species from the overstory and these species are replaced by more shade-tolerant ones, then the windthrow can be viewed as accelerating succession (Holzmueller et al. 2012, Mitchell 2013). In the case of whole-stand replacement, the potential exists for early-serial tree species to occupy the disturbed large areas, leading to uniform stands. The dependence of species composition change on the damage severity was reported by llisson et al. (2007) in a Norway spruce-dominated forest in Estonia. The biodiversity (number of species) was the highest in the areas with moderate damage followed by heavily damaged ones. Despite the severity of damage, the stand attributes are also important factors driving the successional dynamics after wind-induced changes (Shorohova et al. 2008). Holzmueller et al. (2012) reported the species composition change after the strong windthrow in an oak-dominated forest caused by the release of shade-tolerant tree species present in the understory. Studies conducted by Močalov \& Lässig (2002) in boreal forests in Central Ural also showed the significant increase in the number of broadleaved tree species, mostly downy birch and European aspen, after the windstorm. Recruits were most abundant on sites where woody debris was cleared.

While most previously conducted research focused on the effect of the disturbance on species composition change and the dependence of the regeneration on the microhabitat variation, only a few have focused on the spatial structure of regeneration and its subsequent growth (Kuuluvainen \& Juntunen 1998, Nagel et al. 2006, Xi et al. 2008, Allen et al. 2012). Kuuluvainen \& Juntunen (1998) reported a clumped distribution of pine and birch regeneration in the disturbed microhabitats created by fallen trees, but they found that pine seedlings/saplings were less aggregated than birch. Kuuluvainen \& Kalmari (2003) investigated the regeneration of Norway spruce in the windthrow area of boreal oldgrowth forest in Finland, finding that more than $60 \%$ of the seedlings showed aggregated distribution across microsite types created by the wind storm. Nagel et al. (2006) reported that the spatial pattern, as well as the stand structure, showed dependence on the disturbance event in an oldgrowth Fagus-Abies forest. Beech saplings showed clumped distribution at small and medium spatial scales and their clumping intensity was slightly higher in the stand damaged by windthrow compared to the undisturbed one. Fir saplings showed an aggregation pattern only at a small spatial scale, which was also higher in the case of the windthrow plot (Nagel et al. 2006). Allen et al. (2012) analyzed 25 years of change in wind-damaged oak and pine-dominated stands in Minnesota, USA. Their study indicated that after disturbance the stands were converging towards a late-successional forest type dominated by the shade-tolerant tree species and the windstorm in both stands led to a more clumped distribution of the survived trees. Tree regeneration did not show any significant differences from random distribution in the case of the pine-dominated stand. In the oak-dominated plot, the trees showed random distribution prior to disturbance. Afterward, the spatial pattern of regeneration showed clumping only at the finer spatial scales due to the recruits' occurrence in the treefall gaps. Overall, the authors stated that the windthrow weakly modified the spatial pattern of the trees in the oak site; the modification of the spatial pattern was more pronounced in the pine site. Their results also showed that the recruits that had occurred after the windthrow were randomly distributed around the overstory trees in the pine-dominated stand, but showed a positive spatial dependence on the dead overstory trees at the small spatial scale in the oak-dominated site (Allen et al. 2012).

Knowledge of the spatial distribution of trees, including species and size attributes, allows to better understand forest dynamics and growth as most natural processes operate at a certain spatial scale (Lähde et al. 1999, Stoyan \& Penttinen 2000, Koukoulas \& Blackburn 2005, McElhinny et al. 2006, Pukkala \& Gadow 2012). The present paper is focused on the structural diversity of the natural regeneration observed in a continental lowland temperate forest in Poland in the eleven years following the windthrow of 2002. The purposes of the present paper were, first, to evaluate the effect of the disturbance event on three different spatial aspects (i.e., horizontal distribution, species mingling and spatial size differentiation) of the structure of the young generation growing in the forest areas that experienced different disturbance severity. Second, the overall structural diversity index, being the summation of the weighted different structural indices, was calculated to assess the overall struc- tural complexity of regeneration depending on the disturbance severity observed in the forest.

\section{Material and methods}

\section{Study area}

The study was conducted in the Piska Forests located on the Mazurska Plain in northeastern Poland ( $21^{\circ} 48^{\prime} \mathrm{E}, 53^{\circ} 38^{\prime} \mathrm{N}$ ). The region is rather flat and the altitude of the hills ranges from 110 to $190 \mathrm{~m}$ a.s.l. The character of the region (a multitude of lakes and hills) has been formed by the last Baltic glacial period. The forests consist mainly of Scots pine (Pinus sylvestris L.) that cover about $84 \%$ of the area. Other tree species are black alder (Alnus glutinosa L.), silver birch (Betula verrucosa Ehrh.) and Norway spruce (Picea abies (L.) Karst). Most of the stands in the forest district are 30 to 70 years old. Birch and pine are the pioneer tree species that dominate the landscape. The stands of the Szast PF showed different levels of disturbance severity. In some areas, almost all the trees were snapped, and others presented only a few dead trees. The trees in most of the stands that suffered severe blowdown were of a similar age. The pine and oak regeneration is heavily browsed by red deer (Cervus elaphus L.) and roe deer (Capreolus capreolus L.) in all the stands of the Piska Forests (Dobrowolska 2015).

A severe climate with changeable weather is typical of this area. The total precipitation is $541 \mathrm{~mm}$ year-1 with the majority falling in the summer. The average annual temperature is $7^{\circ} \mathrm{C}$ and the vegetation season lasts 190-220 days. Soils are of glacial origin and are composed mainly of sands, boulder clays, or alluvial cones.

The observations were carried out in Szast Protected Forest (Szast PF), which was established 3 years after the wind disturbance of 2002. The total area of the Szast PF is 445 ha, and no management activity has been conducted on this area after its establishment as a protected forest. This area is secured against fire on one side by the Pisa River and on the other side by a $70 \mathrm{~m}$ wide protection belt (Dobrowolska 2007). The main criteria for choosing the study plots were the forest site type and the disturbance intensity. According to Polish site classification (Mroczkiewicz \& Trampler 1964), the dominant forest site type based on the natural potential vegetation is fresh coniferous forest (Peucedano-Pinetum association), and the study was conducted on this site type. On the basis of the aerial photos, a map of the disturbed forest stands was created. The degree of forest damage was estimated based on stereoscopic image observations. Images were acquired on 14 November 2002 in 1: 15.000 scale by an analogue camera with a fixed focal length of 153.172 $\mathrm{mm}$ on light sensitive film (Kodak Infrared Aerochrome $^{\circledast}$ 1443). After digitalization and orientation (internal, exterior, and absolu- 
te), manual interpretation and stereo digitalization of areas with varying degrees of damage were performed (Dobrowolska 2015). The next criteria for choosing the site of experimental plots were the number of damaged trees and the disturbance severity observed in a stand (Tab. 1). The study plots were established in the south part of Szast PF in stands differing in age from 43 to 104 years. The old stands were the only ones in the investigated area that were slightly disturbed. Thus, the age of the studied stands was different. The Szast PF was surrounded by stands showing different levels of disturbances. The distance from the research plots to the undamaged stands was approximately $500 \mathrm{~m}$. The source of the pine seeds was the undamaged stands and the living trees in the moderately and severely disturbed stands. Birch produces seed every year in Poland and therefore regenerates abundantly (and naturally) if seed sources are available. Plots were established in the stands with the following levels of disturbance severity:

- plots with slightly disturbed stands - less than $10 \%$ of the trees showed visible damage (snags, dead standing trees), and the plots had very few lying dead trees (Se);

- plots with moderately disturbed stands $11-50 \%$ of the trees showed visible damage, and the plots had a number of snags (Mo);

- plots with severely disturbed stands over $90 \%$ of the trees were damaged, and most trees were snags (or uprooted trees). Although some wood were logged before the establishment of the Szast PF, this occurrence presented an opportunity to investigate the influence of the wood presence on the stand dynamics. These stands were further divided into stands where timber was logged (Sr) and stands with timber left on the ground (SI).

\section{Methods}

Data were collected on 65 circular plots in the regular $50 \times 100 \mathrm{~m}$ grid established in 2005 in four forest compartments representing different degrees of disturbance severity. The number of plots was not evenly distributed between the treatments (disturbance severity) and depended on the area of disturbance severity in the southern part of the Szast PF. The measurements of spatial diversity were completed in 2013. All seedlings ( $\mathrm{h} \leq 0.5 \mathrm{~m})$ and saplings ( $h>0.5 \mathrm{~m}$ and $\mathrm{DBH} \leq 7 \mathrm{~cm}$ ) were measured in the plots of 10 and $100 \mathrm{~m}^{2}$ area, respectively, and they were the subjects of further statistical analysis. The azimuth of each specimen and the distance from the center of each plot to all trees within that plot were measured. The plots with very sparse regeneration (few trees only) were excluded from the analysis. The percentage of study plots covered by natural regeneration (seedlings and saplings) was also described for all the investigated plots (Falinska 1996).
Tab. 1 - Characteristic of the study plots in Szast Protected Forest. (*): basal area in 2005.

\begin{tabular}{llcccc}
\hline Disturbance severity & $\begin{array}{l}\text { Species } \\
\text { composition }\end{array}$ & $\begin{array}{c}\text { Age } \\
(\text { year })\end{array}$ & $\begin{array}{c}\text { Area } \\
(\text { ha) }\end{array}$ & $\begin{array}{c}\text { Plot } \\
\text { number }\end{array}$ & $\begin{array}{c}\text { BA }^{*} \\
\left(\mathbf{m}^{2} \mathbf{h a}^{-1}\right)\end{array}$ \\
\hline Slightly disturbed (Se) & Scots pine & 104 & 15.48 & 24 & 29.22 \\
Moderately disturbed (Mo) & Scots pine & 48 & 15.77 & 21 & 29.77 \\
Severely disturbed - removed wood (Sr) & Scots pine & 43 & 10.94 & 10 & 19.62 \\
Severely disturbed - left wood (Sl) & Scots pine & 46 & 13.40 & 10 & 36.66 \\
\hline
\end{tabular}

To evaluate the overall structural diversity, we calculated the most commonly used structural indices describing diversity with respect to the spatial positioning of the trees, the spatial mingling of tree species and the size differentiation of trees.

\section{Spatial arrangement of trees (W)}

The spatial arrangement of the trees was evaluated using the contagion index $W$. This index was developed by Gadow (1993) and is based on the classification of the angles between neighboring trees. In contrast to distance methods such as the Clark-Evans index, angles do not have to be measured exactly; rather, it is sufficient to classify the angles (Pommerening 2002, Pukkala \& Gadow 2012, Szmyt 2014). This index can take four values in the case of 3 neighbors taken into account: 0; 0.33; 0.66 and 1.0. Values of $W \leq 0.5$ indicate a regular distribution of specimens, $0.5<W \leq 0.6$ indicate a random distribution, while $W>0.6$ indicate a clumped arrangement of trees (Pommerening 2002, Szmyt 2014).

\section{Species diversity (DM)}

Species diversity can be estimated using a spatially explicit index $D M$ (mingling index) elaborated by Gadow (1993). This index describes the degree of mixing of the tree species in the forest and is defined as the fraction of $n$-th nearest neighbor that is of a different species from the "reference tree" (Pommerening 2002, Kint et al. 2003, Pukkala \& Gadow 2012, Szmyt 2012). The index ranges from o (low species diversity) to 1 (high species diversity) and can take 4 values (3 neighbors are taken into account): 0; 0.33 ; 0.66 and 1.0. Homogenous groups of tree species produce low values of the index, while perfectly intermingled species produce high values of $D M$. For our purposes, the value of $D M \leq 0.33$ suggests low species diversity, $0.33<D M \leq 0.66$ suggests moderate species diversity, while the value of $D M>0.66$ indicates high species diversity.

\section{Size diversity $(\mathrm{TH})$}

Tree height was the tree attribute used to describe the size diversity of the young generation in the forest. Height diversity was evaluated using the differentiation index $T H$, commonly applied in forestry (Pommerening 2006, Szmyt \& Ceitel 2011, Szmyt 2012, Szmyt \& Korzeniewicz 2014). The index describes the degree of dissimilarity of the height between neighboring trees. The $T H$ value ranges from o (low differentiation) to 1 (high differentiation). The TH range can be divided into 5 equal classes of size differentiation (Vorčak et al. 2006). For the purpose of this paper, values of $T H \leq 0.40$ indicate low size diversity, $0.40<T H \leq 0.60$ indicate moderate size diversity and $T H>0.60$ indicate high size diversity.

\section{Complex structural diversity index (SI)}

The complex diversity index is composed of three indices describing the spatial positioning of trees, species diversity and size differentiation, each of which receives a different weight (Pastorella \& Paletto 2013). In the original form, tree diameter was the characteristic used in the size differentiation-index calculations. In the present study, we used the tree height parameter instead of the stem diameter to calculate the size diversity index. The SI index is the weighted sum of three indices and the weight for each component was estimated considering the relative importance of the three variables (i.e., indices too) described above (McElhinny et al. 2006, Pastorella \& Paletto 2013). The weighted SI index is calculated as follows (eqn. 1):

$$
S I=\left(D M \cdot w_{D M}\right)+\left(W \cdot w_{W}\right)+\left(T H \cdot w_{T H}\right)
$$

where $D M$ is the mingling index, $W$ is the spatial arrangement index; $T H$ is the height differentiation index, and the weights $w$ were: $w_{\mathrm{DM}}=0.5, w_{\mathrm{W}}=0.3$ and $w_{\mathrm{TH}}=0.2$, according to Pastorella \& Paletto (2013).

An $S I<0.3$ indicates low diversity, $0.3<$ $S I<0.4$ indicates moderate diversity and $S I \geq 0.4$ indicates high overall diversity of tree regeneration. To determine whether plots with different severities of damage are different with respect to the overall diversity, we used one-way ANOVA.

The effect of the disturbance severity on the ground cover as a result of the regeneration was tested using the Kruskal-Wallis test.

\section{Results}

\section{Ground cover and species composition} of regeneration

The disturbance severity did not influence the ground cover by regeneration (Fig. 1). The regeneration cover varied across the study area. The highest cover was observed in the severely disturbed stands with unlogged wood. The lowest cover was 


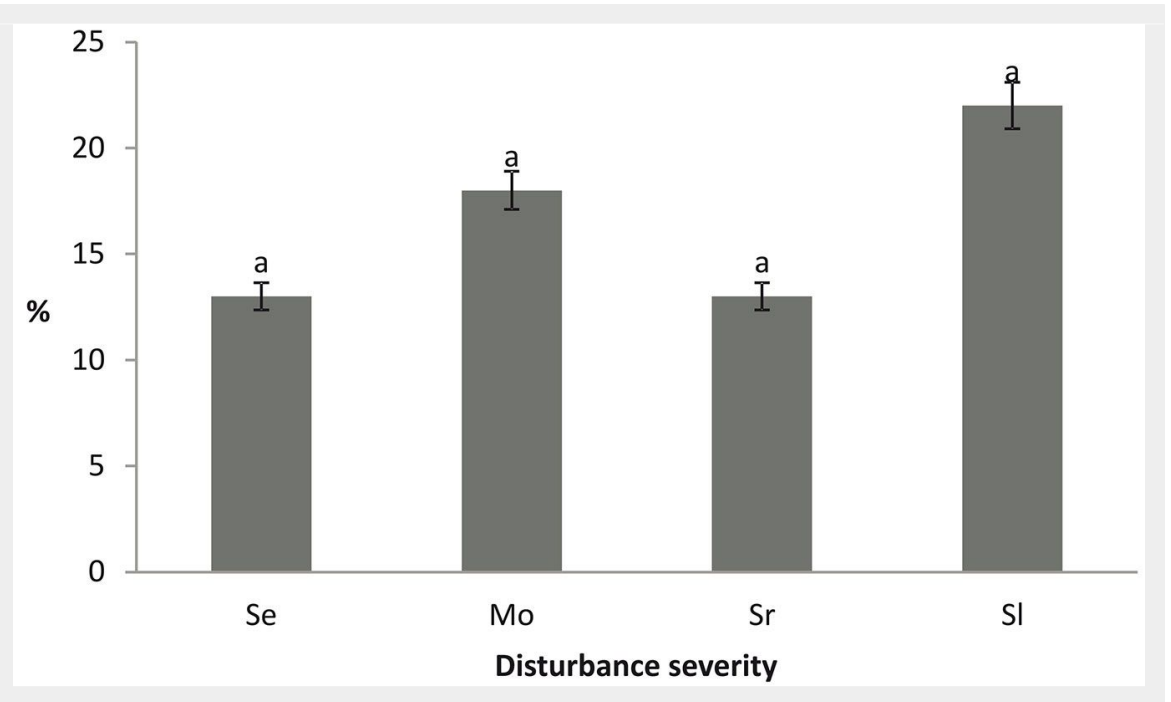

Fig. 1 - Regeneration cover (\%) in the Szast Protected Forest.

measured in the stands with slight and se- stands. The seedlings of European beech vere blowdown and with salvage logging. (Fagus sylvatica L.) and Norway spruce (PiThe seedlings of Scots pine dominated in cea abies (L.) Karst) were found only in the the moderately disturbed stands (Fig. 2a). slightly disturbed stand. Young growth of The lowest percentage of pine seedlings silver birch (Betula pendula Roth) was abwas observed in the severely disturbed sent in the severely disturbed stand with

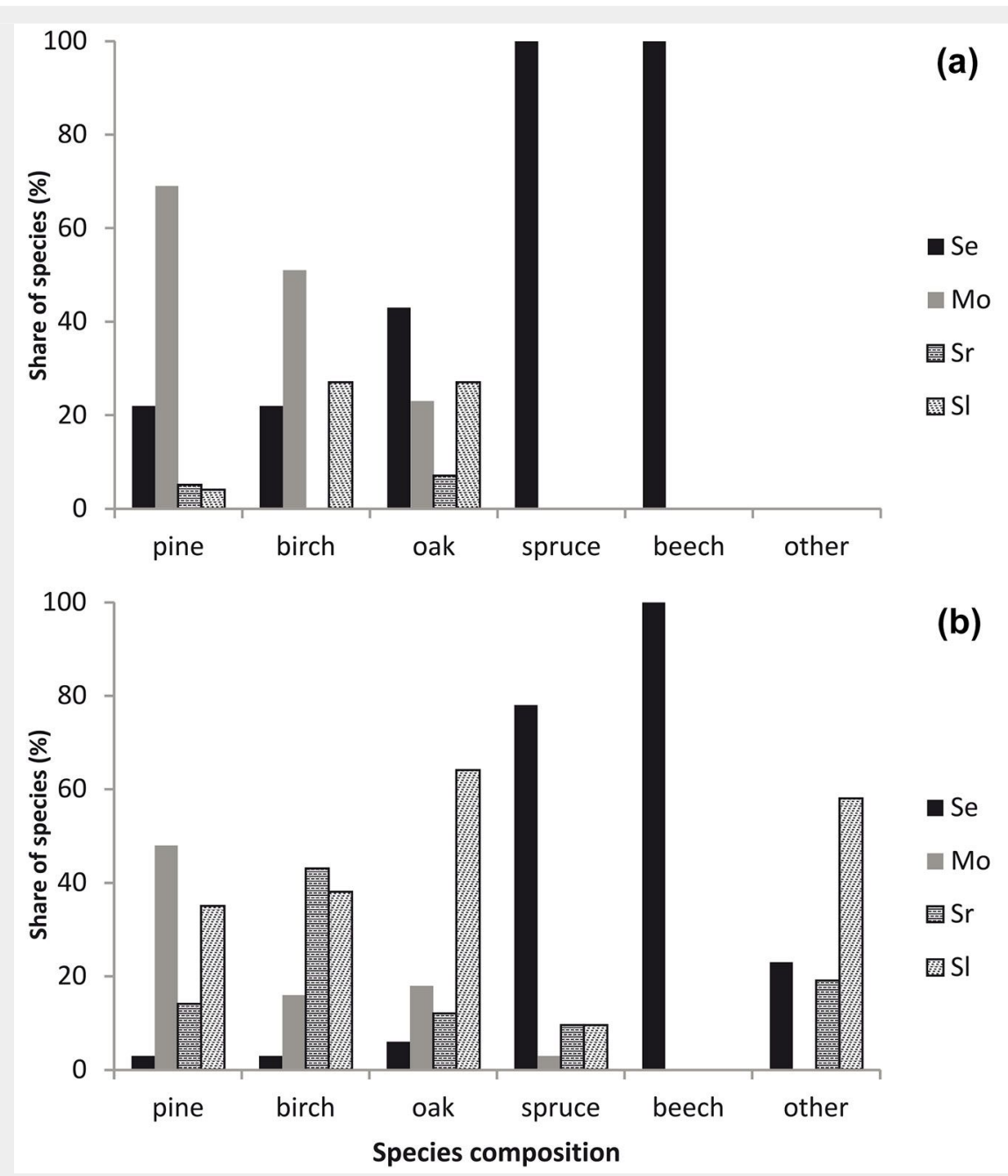

Fig. 2 - Seedlings and saplings in the Szast Protected Forest depending on the severity of disturbance. logged wood and the density of pedunculate oak (Quercus robur L.) seedlings was the highest in the slightly and severely disturbed stand with unlogged timber.

Scots pine was the dominant tree species in the sapling phase in the moderately disturbed stands (Fig. 2b). The percentage of pine saplings was also high in the severely disturbed stands with unlogged wood. Birch dominated in the severely disturbed stand with logged timber. The percentage of oak was the highest in the severely disturbed stands without salvage logging. Saplings of spruce were found in all the investigated stands with the highest percentage in the slightly disturbed forests. Other species (mainly shrubs) were observed in all stands, except the moderately disturbed stands, and the highest percentage was found in the severely disturbed stands with unlogged wood.

Spatial pattern of natural regeneration Natural regeneration occurred mostly at random in the moderately disturbed stands and in both variants of the severely disturbed stands. The trees were established at random, especially in the severely disturbed forests where timber was not removed (70\% of plots in $\mathrm{SI})$. In the case of the slightly disturbed forest (Se), the prevailing type of tree distribution was regular (Tab. 2). This regular type of tree arrangement could be observed on $40 \%$ of the plots established in this part of the forest. A clumping distribution of the young forest generation was often observed on the plots located in each part of the forest, irrespective of the disturbance severity, but their share varied from $20 \%(\mathrm{SI})$ to $37.5 \%(\mathrm{Sr})$. The clusters were observed on $25-26 \%$ of the plots in the forest areas with slight and moderate disturbance (Se and Mo, respectively). The coefficient of variability for the $W$-index was highest in the severely disturbed part of the forest with removed timber ( $\mathrm{Sr}, \mathrm{CV}=0.63 \%)$, and its lowest value was found for the moderately disturbed stand (Mo, $\mathrm{CV}=15 \%$ ).

\section{Diversity measures}

\section{Species mingling ( $D M$ index)}

The severely disturbed stand with timber left on the ground (SI) was the most diverse. At least two of the three closest neighbors belonged to other tree species than the reference tree (Tab. 2). The lowest diversity of tree species was observed in $\mathrm{Sr}$ (62\% of the study plots). In the slightly (Se) and moderately (Mo) disturbed stands, the species diversity was lower (45 and $47 \%$ of plots, respectively) than that in Sr. However, the species diversity was the highest (different tree species recorded for 3 neighbors) on only two plots in Se and one plot in Mo. These results were confirmed by the distribution of the $D M$ index (results not shown), indicating that at least 2 closest neighbors belonged to the same species as the reference tree in Mo and Sr. 
Tab. 2 - Indices of structural diversity of natural regeneration in disturbed stands of the Szast Protected Forest. (DM): spatial mingling index; $(W)$ : contagion index; $(T H)$ : tree height differentiation index; (SI): complex structural index); (Se); slightly disturbed stand; (Mo): moderately disturbed stand; (Sr): severely disturbed stand with removed wood; (Sl): severely disturbed stand with left wood.

\begin{tabular}{|c|c|c|c|c|c|c|c|c|c|c|c|c|c|c|c|}
\hline$W$ & & & & $D M$ & & & & $T H$ & & & & $S I$ & & & \\
\hline $\mathrm{Se}$ & Mo & $\mathrm{Sr}$ & SI & $\mathrm{Se}$ & Mo & $\mathrm{Sr}$ & SI & $\mathrm{Se}$ & Mo & $\mathrm{Sr}$ & SI & $\mathrm{Se}$ & Mo & $\mathrm{Sr}$ & SI \\
\hline 0.53 & 0.38 & 0.00 & 0.59 & 0.45 & 0.41 & 0.43 & 0.60 & 0.47 & 0.47 & 0.55 & 0.57 & 0.48 & 0.41 & 0.33 & 0.59 \\
\hline 0.56 & 0.49 & 0.58 & 0.59 & 0.13 & 0.00 & 0.50 & 0.57 & 0.51 & 0.34 & 0.63 & 0.50 & 0.34 & 0.22 & 0.55 & 0.56 \\
\hline 0.50 & 0.76 & 0.75 & 0.51 & 0.16 & 0.51 & 0.00 & 0.46 & 0.48 & 0.55 & 0.48 & 0.40 & 0.33 & 0.59 & 0.32 & 0.46 \\
\hline 1.00 & 0.62 & 0.56 & 0.57 & 0.58 & 0.08 & 0.49 & 0.54 & 0.54 & 0.29 & 0.51 & 0.44 & 0.70 & 0.28 & 0.52 & 0.53 \\
\hline 0.57 & 0.50 & 0.00 & 0.75 & 0.40 & 0.49 & 0.00 & 0.57 & 0.51 & 0.52 & 0.55 & 0.50 & 0.47 & 0.50 & 0.11 & 0.61 \\
\hline 0.74 & 0.51 & 0.62 & 0.58 & 0.40 & 0.57 & 0.24 & 0.58 & 0.53 & 0.61 & 0.48 & 0.56 & 0.53 & 0.56 & 0.40 & 0.58 \\
\hline 0.56 & 0.50 & 0.57 & 0.00 & 0.00 & 0.37 & 0.32 & 0.42 & 0.48 & 0.45 & 0.46 & 0.52 & 0.26 & 0.43 & 0.42 & 0.31 \\
\hline 0.61 & 0.65 & 0.63 & 0.52 & 0.43 & 0.08 & 0.32 & 0.49 & 0.60 & 0.56 & 0.47 & 0.55 & 0.52 & 0.35 & 0.44 & 0.51 \\
\hline 0.00 & 0.51 & - & 0.58 & 0.54 & 0.88 & - & 0.53 & 0.38 & 0.63 & - & 0.59 & 0.35 & 0.72 & - & 0.56 \\
\hline 0.42 & 0.60 & - & 0.67 & 0.67 & 0.39 & - & 0.42 & 0.67 & 0.58 & - & 0.55 & 0.60 & 0.49 & - & 0.52 \\
\hline 0.00 & 0.72 & - & - & 0.20 & 0.53 & - & - & 0.67 & 0.43 & - & - & 0.23 & 0.57 & - & - \\
\hline 0.37 & 0.60 & - & - & 0.33 & 0.08 & - & - & 0.51 & 0.42 & - & - & 0.38 & 0.30 & - & - \\
\hline 0.00 & 0.53 & - & - & 0.67 & 0.17 & - & - & 0.56 & 0.48 & - & - & 0.45 & 0.34 & - & - \\
\hline 0.61 & 0.54 & - & - & 0.63 & 0.36 & - & - & 0.66 & 0.47 & - & - & 0.63 & 0.44 & - & - \\
\hline 0.50 & 0.60 & - & - & 0.30 & 0.3 & - & - & 0.52 & 0.49 & - & - & 0.40 & 0.43 & - & - \\
\hline 0.55 & 0.56 & - & - & 0.26 & 0.21 & - & - & 0.60 & 0.4 & - & - & 0.42 & 0.35 & - & - \\
\hline 0.00 & 0.59 & - & - & 0.62 & 0.62 & - & - & 0.66 & 0.69 & - & - & 0.44 & 0.63 & - & - \\
\hline 0.52 & 0.58 & - & - & 0.46 & 0.23 & - & - & 0.62 & 0.36 & - & - & 0.51 & 0.36 & - & - \\
\hline 0.65 & 0.67 & - & - & 0.11 & 0.00 & - & - & 0.68 & 0.55 & - & - & 0.39 & 0.31 & - & - \\
\hline 0.55 & - & - & - & 0.22 & - & - & - & 0.35 & - & - & - & 0.35 & - & - & - \\
\hline
\end{tabular}

Thus, in these sites, the natural regeneration was rather homogenous in terms of species composition at the nearest neighbor scale. The distribution of the $D M$ index suggested a greater differentiation of plots in Se and Sl because there were more cases when two or three neighbors belonged to different species than the reference tree. The spatial mixture of the tree species was different in particular stands (Tab. 3). Scots pine created homogenous clusters in the slightly disturbed stands (Se) and oak was the single mixed-tree species in the same site. Beech and spruce were found spatially mixed between the Scots pine and oak. Scots pine created homogenous clusters also in Mo $(D M=0.15)$. Birch occurred individually $(D M=0.65)$ both in Mo and Sr. Homogenous clusters of Scots pine and birch were also found in $\mathrm{Sr}$ (Tab. 3). The tree species (Scots pine, pedunculate oak and silver birch) did not show any trend in terms of species mingling in Sl. The coefficient of variability for the average $D M$ index ranged from 13 to $72 \%$.

\section{Height diversity (TH index)}

The spatial diversity of the tree height was moderate $(0.4<T H<0.6)$ or high $(\mathrm{TH}>0.6)$ in the investigated stands. $\mathrm{TH}$ values ranged from 0.36 to 0.68 in the slightly disturbed stands (11 plots exhibited medium diversity, 9 high diversity). Medium tree height differentiation dominated in the moderately disturbed stands (16 plots in Mo). Only in the case of three plots did the trees show a high diversity of this tree characteristic. The $T H$ index in the severely disturbed parts of the forest ( $\mathrm{Sr}$ and $\mathrm{Sl}$ ) was moderately diverse in terms of tree height (Tab. 2). The distribution of the $T H$ values in the differentiation classes (results not shown) confirmed the medium and high diversity of tree height. The coefficient of variability for the height differentiation index, which ranged from 11 to $21 \%$, was the lowest in comparison to all of the analyzed spatial indices. The lowest values of $\mathrm{CV}$ were observed in both variants of the severely disturbed forest (12 and 13\%), while the highest $\mathrm{CV}$ was recorded for the moderately disturbed stand (21\%).

\section{Complex structural diversity (SI index)}

The range of the $S I$ index values distinctly differed between the parts of the forest with different disturbance severity. The forests with slight or moderate disturbance showed a wider range of SI values; in contrast, the severely disturbed forests showed a narrower range (Tab. 2).

In the plots located in slightly disturbed parts of the forest (Se), the most abundant were those that can be described by the random distribution of trees with low species diversity and moderate differentiation of tree height ( 5 cases). For these

plots, the complex diversity index ranged from 0.26 to 0.48 . Three plots (the second rank) showed a clumped arrangement of specimens and moderate species and height diversity, with $S I$ index values ranging from 0.52 to 0.70 . One of these plots showed the highest $S I$ value observed in this part of the forest. The lowest overall structural diversity was observed for the plot with a regular distribution of trees with small species diversity but with a high diversity of tree height ( $S I=0.23)$.

In the moderately disturbed stands (Mo), the most abundant plots were those with a random arrangement of specimens, with moderate species diversity and moderate tree height differentiation (4 cases). The $S I$ index calculated for these sites ranged from 0.43 to 0.50 . The highest value of complex structural diversity was found for the plot with a random distribution of trees and high diversity with respect to species composition and tree height ( $S I=0.72)$. The lowest $S I$ value was recorded for the plot in which trees were regularly dispersed and

Tab. 3 - Average values of the $D M$ index for particular tree species growing in disturbed stands of the Szast Protected Forest (values in parenthesis are the range of $D M$ for plots).

\begin{tabular}{|c|c|c|c|c|}
\hline \multirow{2}{*}{ Species } & \multicolumn{4}{|c|}{$D M$ Index } \\
\hline & $\mathrm{Se}$ & Mo & $\mathrm{Sr}$ & SI \\
\hline Scots pine & $\begin{array}{c}0.26 \\
(0.19-0.50)\end{array}$ & $\begin{array}{c}0.15 \\
(0-0.47)\end{array}$ & $\begin{array}{c}0.24 \\
(0-0.42)\end{array}$ & $\begin{array}{c}0.41 \\
(0.29-0.62)\end{array}$ \\
\hline Norway spruce & $\begin{array}{c}0.34 \\
(0.03-0.70)\end{array}$ & - & - & - \\
\hline Pedunculate oak & 0.85 & 0.08 & - & $\begin{array}{c}0.63 \\
(0.45-0.80)\end{array}$ \\
\hline Silver birch & - & $\begin{array}{c}0.65 \\
(0.37-0.94)\end{array}$ & $\begin{array}{c}0.28 \\
(0.13-0.78)\end{array}$ & $\begin{array}{c}0.54 \\
(0.38-0.67)\end{array}$ \\
\hline European beech & $\begin{array}{c}0.36 \\
(0-0.83)\end{array}$ & - & - & - \\
\hline
\end{tabular}


which presented low species and height diversity $(S I=0.22)$.

In the severely disturbed part of the forest with timber left on the ground, the most abundant plots were characterized by the clumped distribution of specimens, the low species diversity and the moderate differentiation of tree height (3 cases). The $S I$ values for these plots ranged from 0.32 to 0.44 . The highest SI was observed for the plot where trees were randomly dispersed and showed moderate species diversity and high tree height differentiation $(S I=0.55)$. The lowest $S I$ index was found in the case of the regular arrangement of specimens with a low species diversity and moderate tree height differentiation ( $S I=$ 0.11).

Plots located in the severely disturbed part of the forest where timber was removed could be described by the random allocation of trees with moderate species and height diversity ( 6 cases). The SI for these plots ranged from 0.51 to 0.59 . The highest value of the complex structural diversity index was found in the case of the clumped distribution of trees and moderate species and height diversity $(S I=0.61)$, whereas its lowest value was found on the plot with regular tree dispersion and moderate species and tree height differentiation.

\section{Discussion}

\section{Species abundance and composition of} regeneration

Regeneration covered less than $25 \%$ of the study plots. The process of regeneration began just after the wind blowdown and will continue in the upcoming years. The regeneration cover in the slightly disturbed stands was lower than $15 \%$. The high density of surviving tree species negatively influenced the recruitment of new regeneration (Dobrowolska 2015). In severely disturbed stands, increased light stimulates seed germination and the growth of seedlings present in the seedling bank (Uriarte et al. 2005).

The highest diversity of young growth (seedlings and saplings) was found in the forest with severe disturbance and without any salvage logging. In contrast, the severely disturbed forests with partial salvage logging were characterized by a lower share of trees, similar to the situation observed on the slightly disturbed plots. In the first case, a lower level of regeneration could be attributed to logging, which could destroy already established seedlings and saplings (Močalov \& Lässig 2002, Peterson \& Leach 2008, Shorohova et al. 2008). The lowest share of young growth observed on the slightly disturbed plots could result from the insufficient amount of light reaching the ground because of the remaining tree canopy, thus preventing the establishment of a new generation of trees. In contrast to our results, Schönenberger (2002) reported that in the case of mountain fo- rests, the salvage-logged windthrow areas showed generally higher levels of natural regeneration than those observed in unharvested areas. Similar conclusions were drawn for lowland spruce forests by llisson et al. (2007). Močalov \& Lässig (2002) reported that regeneration in windthrow areas in Central Ural was the most abundant on sites where woody debris was cleared after the disturbance and the lowest on those that were not cleared.

On the other hand, Peterson \& Leach (2008) reported a lack of significant differences in the density of tree seedlings in salvaged and unsalvaged areas 2 years after the wind storm, although the first had a greater variety of microsites.

Our findings confirmed the general statement that the occurrence of a natural disturbance can modify the species composition of the stand and increase overall biodiversity (Ilisson et al. 2007, Fischer et al. 2013). In the Szast PF, Scots pine was the main tree species before the disturbance. Subsequently, pine still dominated in the regeneration on most plots, but other tree species - oak, birch, beech and spruce were found as well. In addition to pioneer tree species (pine and birch), late successional tree species (e.g., beech) may occur in the regeneration. The presence of beech was, however, associated with the slight disturbance of the tree canopy. A low disturbance level creates sufficient light conditions beneath the canopy, favoring the growth of light intolerant tree species such as beech or spruce. Oak, a more light demanding species than beech or spruce, was found at each level of disturbance but was the most abundant in the severely disturbed plots without logging. The severity of disturbance can modify the species composition in different ways. In the case of the totally devastated stands where all the overstory trees are damaged, the potential exists for early successional tree species that can then occupy large areas after the windthrow. Gap replacement, where canopy gaps are created by the death of single to several overstory trees, can lead to a mixed regime of cohort replacement and to forests dominated by shade-tolerant tree species. It is obvious that the success of regeneration depends also on the presence of the seed bank within the landscape, as well as the capacity of the tree species to regenerate on the microsites created by the windthrow (Oliver \& Larson 1996, Nachtergale et al. 1997, Szewczyk \& Szwagrzyk 1996, Mitchell 2013).

\section{Spatial pattern of natural regeneration}

The nonrandom distribution of seedlings and saplings is usually attributed to the microsite mosaic created by the disturbance (Kuuluvainen \& Kalmari 2003, Nagel et al. 2006, Thaxton et al. 2007, Xi et al. 2008, Allen et al. 2012, Fischer et al. 2013). The most common pattern of seedling and sapling distribution in the case of the analysed stands was random, which was pre- sent regardless of the disturbance severity in the forest. The clumped or hyperdispersed distribution of regeneration was found much less often. For example, the random distribution of regeneration at the large spatial scale after the disturbance was reported by Allen et al. (2012). Nagel et al. (2006) noted the clumped distribution of seedlings and saplings of fir and beech after the windthrow in southern Slovenia. Also Kuuluvainen \& Juntunen (1998) and Kuuluvainen \& Kalmari (2003) documented the aggregated distribution of pine, birch and spruce regeneration in the disturbed areas. The prevailing random distribution in young growth can be partly attributed to the low number of uprooted trees and the high number of snapped trees (Dobrowolska 2008). Uprooted trees create specific microhabitats, the so-called pits and mounds, which are very suitable for the germination of new seedlings and their further growth, and such microsites would be more favorable for the non-random spatial pattern of recruits.

\section{Species mingling and size}

\section{differentiation in regeneration}

Our results showed that only Scots pine was characterized by more homogenous structural groups of regeneration than the other tree species. This structural grouping was pronounced, especially on the plots with moderate disturbance. In contrast to pine, oaks were scattered among the other tree species, creating more differentiated species groups. The scattered distribution of oaks may be attributed to the dispersion of acorns by jays, which is a common way of propagation (Mosandl \& Kleinert 1998). Birch trees were scattered among other trees species in the severely disturbed stands, both with and without logging, but birch formed more homogenous groups in the moderately damaged stand. This spatial pattern of birch regeneration could be attributed to the fact that most trees were snapped but not uprooted. For example, Kuuluvainen \& Juntunen (1998) reported that birch recruits avoided undisturbed ground and preferred uprooting spots. Pine regeneration took place at ground level, as well as on or beside downed logs and stumps. They note also that both species differed in respect to the local relief and that pine recruits occurred generally closer to the ground. While there are many examples in the literature of the effect of windthrow on species composition change (Ulanova 2000, Arévalo et al. 2000, Xi et al. 2008, Dobrowolska 2010, Holzmueller et al. 2012, Budzáková et al. 2013) and the relationships between gaps, disturbed microsites and the occurrence and growth of regeneration, there are no reports about how windthrow affects the regeneration structure with respect to tree size. Our results indicated rather high differentiation in young growth height. This negative spatial autocorrelation of tree height indicated that trees of different height existed as 
patches and a local size hierarchy developed 11 years after the windthrow. After an extensive windstorm, a substantial part of natural regeneration is formed by broadleaved species (birch, oak, and beech), which is probably due to the disturbed soil surface, increased light level (oak and beech), and the easy dispersal of pioneer species seed (birch - Dobrowolska 2015). The plots located in the severely disturbed forest ( $\mathrm{Sr}$ and $\mathrm{Sl}$ ) showed, however, a lower inequality of plant height than was found in the other plots.

\section{Overall diversity of regeneration}

To find the differences between the plots with different disturbance severity, we calculated the overall structural diversity index following Pastorella \& Paletto (2013). The highest values of the index were observed in the plots where mingling and differentiation indices showed high diversity, while the spatial positioning index was of minor significance. In contrast, the lowest overall structural diversity referred mostly to the regular pattern of young growth and low species mingling, irrespective of the disturbance severity in the forest.

\section{Conclusion}

Our study confirmed the significant effect of natural disturbance events on the species composition change in the Szast PF. Even-aged, one-layered monocultures of pine stands before the blowdown can be replaced by a more diversified forest in terms of the spatial distribution of trees, species composition and size differentiation, reflecting a more complex structure. Despite the presence of pioneer trees (pine and birch), late successional tree species (e.g., beech) can be found in the regeneration, and the different damage levels play a role in modifying the species composition and abundance. The number of seedlings and saplings of all trees varied between the stands (Dobrowolska 2015). The most common type of seedling and sapling distribution was random, which occurred independently of the disturbance severity in the forest. The clumped and hyperdispersed distribution patterns of regeneration were observed much less often. Eleven years after the disturbance event young growth of different height existed as patches.

\section{Acknowledgements}

JS wrote the manuscript and analyzed the data; DD designed the experiment, carried out the field measurements, wrote the manuscript. We would like to thank Bogdan Pawlak for his help in the field works. We wish also to thank three anonymous reviewers for valuable suggestions and comments on an earlier version of the manuscript. The study was realized under the project funded by the General Directorate of State Forests (BLP-359) and the Ministry of Sciences and High Education (Grant No. 240110).

\section{References}

Allen MS, Thapa V, Arévalo JR, Palmer MW (2012). Windstorm damage and forest recovery: accelerated succession, stand structure, and spatial pattern over 25 years in two Minnesota forests. Plant Ecology 213: 1833-1842. - doi: 10.10 07/s11258-012-0139-9

Arévalo JR, DeCoster JK, McAlister SD, Palmer MW (2000). Changes in two Minnesota forest during 14 years following catastrophic windthrow. Journal of Vegetation Science 11: 833840. - doi: $10.2307 / 3236553$

Budzáková M, Galvanek D, Littera P, Sibik J (2013). The wind and fire disturbance in Central European mountain spruce forests: the regeneration after four years. Acta Societatis Botanicorum Poloniae 82: 13-24. - doi: 10.5586/asbp.20 13.002

Dobrowolska D (2007). Odnowienie naturalne lasu w drzewostanach uszkodzonych przez wiatr na terenie pólnocno-wschodniej Polski [Natural regeneration of forests in stands damaged by wind in north-eastern Poland]. Lesne Prace Badawcze 2: 45-60. [in Polish]

Dobrowolska D (2008). Odnowienie naturalne na powierzchniach uszkodzonych przez pozar w Nadlesnictwie Rudy Raciborskie [Natural regeneration in fire-damaged plots in the Rudy Raciborskie Forest Division]. Lesne Prace Badawcze 3: 255-264. [in Polish]

Dobrowolska D (2010). Rola zaburzen w regeneracji lasu. [The role of disturbance in forest regeneration]. Lesne Prace Badawcze 7: 391-405. Dobrowolska D (2015). Forest regeneration in northeastern Poland following a catastrophic blowdown. Canadian Journal of Forest Research 45: 1172-1182. - doi: 10.1139/cjfr-2014-0507 Falinska K (1996). Ekologia roslin [Vegetation ecology]. Wydawnictwo Naukowe PWN, Warszawa, Poland, pp. 454. [in Polish]

Fischer A, Marshall P, Camp A (2013). Disturbances in deciduous temperate forest ecosystems of the northern hemisphere: their effects on both recent and future forest development. Biodiversity Conservation 22: 1863-1893. - doi: 10.1007/s10531-013-0525-1

Gadow KV (1993). Zur Bestandesbeschreibung in der Forsteinrichtung [New variables for describing stands of trees]. Forst und Holtz 48: 602606. [in German]

Holzmueller EJ, Gibson DJ, Suchecki PF (2012). Accelerated succession following an intense wind storm in an oak-dominated forest. Forest Ecology and Management 279: 141-149. - doi: 10.1016/j.foreco.2012.05.036

Ilisson T, Köster K, Vodde F, Jõgiste K (2007). Regeneration development 4-5 years after a storm in Norway spruce dominated forests, Estonia. Forest Ecology and Management 250: 17-24. - doi: 10.1016/j.foreco.2007.03.022

Kint V, Van Meirvenne M, Nachtergale L, Geudens G, Lust N (2003). Spatial methods for quantifying forest structure development: a comparison between nearest-neighbor indices and variogram analysis. Forest Science 49: 3649. [online] URL: http://www.ingentaconnect. com/content/saf/fs/2003/00000049/00000001/ arto0003

Kulakowski D, Veblen TT (2003). Subalpine forest development following a blowdown in the Mount Zirkel Wilderness, Colorado, USA. Jour- nal of Vegetation Science 14 (5): 653-66o. - doi: 10.1111/j.1654-1103.2003.tbo2197.x

Koukoulas S, Blackburn GA (2005). Mapping individual tree location, height and species in broadleaved deciduous forest using airborne LiDAR and multi-spectral remotely sensed data. International Journal of Remote Sensing 26: 431-455. - doi: 10.1080/0143116042000298289 Kuuluvainen T, Kalmari R (2003). Regeneration microsites of Picea abies seedlings in a windthrow area of a boreal old-growth forest in southern Finland. Annales Botanici Fennici 40 (6): 401-413. [online] URL: http://www.jstor. org/stable/23726798

Kuuluvainen T, Juntunen P (1998). Seedling establishment in relation to microhabitat variation in a windthrow gap in a boreal Pinus sylvestris forest. Journal of Vegetation Sciences 9: 551562. - doi: 10.2307/3237271

Lähde E, Laiho O, Norokorpi Y, Saksa T (1999). Stand structure as the basis of diversity index. Forest Ecology and Management 115: 213-220. doi: 10.1016/S0378-1127(98)00400-9

Močalov SA, Lässig R (2002). Development of two boreal forests after large-scale windthrow in the Central Urals. Forest Snow and Landscape Research 77: 171-186. [online] URL: http:// www.issw.ch/dienstleistungen/publikationen/p df/4748.pdf

McElhinny C, Gibbons P, Brack C, Bauhus J (2006). Forest and woodland stand structural complexity: its definition and measurement. Forest Ecology and Management 218: 1-24. doi: 10.1016/j.foreco.2005.08.034

Mitchell SJ (2013). Wind as a natural disturbance agent in forests: a synthesis. Forestry 86 (2): 147-157. - doi: 10.1093/forestry/cps058 Mosandl R, Kleinert A (1998). Development of oaks (Quercus petraea (Matt). Liebl.) emerged from bird-dispersed seeds under old-growth pine (Pinus silvestris L.) stands. Forest Ecology and Management 106: 35-44. - doi: 10.1016/So 378-1127(97)00237-5

Mroczkiewicz L, Trampler T (1964). Typy siedliskowe lasu w Polsce [Forest site types in Poland]. PWRiL, Warszawa, Poland, pp. 1-16o. [in Polish]

Nachtergale L, Schrijver DE, Lust N (1997). Windthrow, what comes after the storm? Silva Gandavensis 62: 80-89.

Nagel TA, Svoboda M, Diaci J (2006). Regeneration patterns after intermediate wind disturbance in an old-growth Fagus-Abies forest in southeastern Slovenia. Forest Ecology and Management 226: 268-278. - doi: 10.1016/j.foreco. 2006.01.039

Oliver CD, Larson BC (1996). Forest stand dynamics. John Wiley and Sons, New York, USA, pp. 544.

Panayotov M, Kulakowski D, Laranjeiro Dos Santos L, Bebi P (2011). Wind disturbances shape old Norway spruce-dominated forest in Bulgaria. Forest Ecology and Management 262: 470481. - doi: 10.1016/j.foreco.2011.04.013

Pastorella E, Paletto A (2013). Stand structure indices as tools to support forest management: an application in Trentino forests (Italy). Journal of Forest Science 4: 159-168. [online] URL: http://81.0.228.28/publicFiles/90901.pdf

Peterson CJ, Leach AD (2008). Salvage logging after windthrow alters microsite diversity, 
abundance and environment, but not vegetation. Forestry 81 (3): 361-376. - doi: 10.1093/fo restry/cpnoo7

Pommerening A (2002). Approaches to quantifying forest structures. Forestry 75: 305-324. - doi: 10.1093/forestry/75.3.305

Pommerening A (2006). Evaluating structural indices by reversing forest structural analysis. Forest Ecology and Management 224: 266-277. doi: 10.1016/j.foreco.2005.12.039

Pukkala T, Gadow KV (2012). Forest structure and diversity. In: "Continuous cover Forestry" (Pukkala T, Gadow KV eds). Springer Science+Business Media BV, Dordrecht, Heidelberg London, New York, pp. 296.

Shorohova E, Fedorchuk V, Kuznetsova M, Shvedova $O$ (2008). Wind-induced successional changes in pristine boreal Picea abies forest stands: evidence from long-term permanent plot records. Forestry 81 (3): 335-359. - doi: 10.1093/forestry/cpno30

Schönenberger W (2002). Post windthrow stand regeneration in Swiss mountain forests: the first ten years after the 1990 storm Vivian. Forest Snow and Landscape Research 77 (1/2): 6180. [online] URL: http://www.bf.uni-lj.si/fileadm in/groups/2716/downloads/Älanki_vaje/Schonen berger_2002.pdf

Spathelf $P$, Maaten E, Maaten-Theunissen M, Campioli M, Dobrowolska D (2014). Climate change impacts in European forests: the expert views of local observers. Annals of Forest Science 71 (2): 131-137. - doi: 10.1007/s13595-013-028 0-1

Stoyan D, Penttinen A (2000). Recent applications of point process methods in forestry statistics. Forest Science 15: 61-78. [online] URL: http://www.jstor.org/stable/2676677
Svoboda M, Pouska V (2008). Structure of a Central-European mountain spruce old-growth forest with respect to historical development. Forest Ecology and Management 255 (7): 21772188. - doi: 10.1016/j.foreco.2007.12.031

Szewczyk J, Szwagrzyk J (1996). Tree regeneration on rotten wood and on soil in old-growth stand. Vegetatio 12: 37-46. - doi: 10.1007/BFooo 52814

Szmyt J, Ceitel J (2011). Zróznicowanie przestrzenne i grubosciowe drzew $\mathrm{w}$ niepielegnowanych drzewostanach sosnowych o róznym zageszczeniu poczatkowym [Spatial and size diversity of trees in untended pine stands of different initial density]. Sylwan 11: 749-760. [in Polish]

Szmyt J (2012). Spatial structure of managed beech-dominated forest: Applicability of nearest neighbors indices. Dendrobiology 68: 6976. [online] URL: http://agro.icm.edu.pl/agro/el ement/bwmeta1.element.agro-bca83128-be6547ao-b3bc-85dcfe9252c6

Szmyt $J$ (2014). Spatial statistics in ecological analysis: from indices to functions. Silva Fennica 48: artID 1008. - doi: 10.14214/sf.1008

Szmyt J, Korzeniewicz R (2014). Czy naturalne procesy ekologiczne $w$ juwenilnej fazie rozwoju drzewostanu zalozonego sztucznie róznicuja jest strukture przestrzenna? [Do natural processes at the juvenile stage of stand development differentiate the spatial structure of trees in artificially established forest stands?] Lesne Prace Badawcze 75: 171-179. [in Polish]

Thaxton JM, DeWalt SJ, Platt WJ (2007). Spatial patterns of regeneration after hurricane Andrew in two south Florida fringe mangrove forests. Biological Sciences 2: 148-156. [online] URL: http://biology.uprm.edu/facultad/publica
tions/Jarrod_Thaxton_20070601_.pdf Ulanova NG (2000). The effect of windthrow on forests at different spatial scales: a review. Forest Ecology and Management 135: 155-167. doi: 10.1016/S0378-1127(00)00307-8

Uriarte M, Canham CD, Thompson J, Zimmerman JK, Brokaw N (2005). Seedling recruitment in a hurricane-driven tropical forest: light limitation, density-dependence and the spatial distribution of parent trees. Journal of Ecology 93: 291304. - doi: 10.1111/j.0022-0477.2005.00984.x Vodde F, Jõgiste K, Gruson L, Ilisson T, Köster K, Stanturf $J$ (2010). Regeneration in windthrow areas in hemiboreal forests: the influence of microsite on the height growths of different tree species. Journal of Forest Research 15 (1): 55-64. - doi: 10.1007/s10310-009-0156-2

Vorčak J, Merganic J, Saniga M (2006). Structural diversity change and regeneration processes of the Norway spruce natural forest in $\mathrm{Ba}$ bia hora NNR in relation to altitude. Journal of Forest Science 52: 399-409. [online] URL: http://www.mzp.cz/ris/ekodisk-new.nsf/6d13bo 04071d0140c12569e700154acb/

Xi W, Peet RK, Urban DL (2008). Changes in forest structure, species diversity and spatial pattern following hurricane disturbance in a Piedmont North Carolina forest, USA. Journal of Plant Ecology 1: 43-57. - doi: 10.1093/jpe/rtmo03 Wohlgemuth T, Kull P, Wüthrich H (2002). Disturbance of microsites and early tree regeneration after windthrow in Swiss mountain forests due to the winter storm Vivian 1990. Forest, Snow and Landscape Research 47: 17-47. [online] URL: http://www.wslf.ch/dienstleistungen/pub likationen/pdf/4706.pdf 